\title{
Újabb varrattechnikai és rehabilitációs módosítások a kéz hajlítóín sérüléseinek helyreállításában
}

\author{
Irodalmi ismertetés
}

\author{
DR. BÍRÓ VILMOS
}

\section{ÖSSZEFOGLALÁS}

Az elmúlt évtizedben a hajlítóín sérülések helyreállításában jelentős számú, forradalmian újnak tekinthető előrelépést figyelhettünk meg, nem csak a sebészi technikában, hanem a posztoperatív rehabilitációban is. A szerző számos irodalmi adatot értékelő munkájában áttekinti az újabb kezelési eljárásokat: első sorban a hat szálból álló, erős rögzítést biztosító és az íncsonkok között jelentős kompressziót létesítő intratendinealis varrat használatát, amely korai, aktív mobilizációt tesz lehetővé. Továbbá ismerteti az epitenon varratok mellőzésének lehetőségét, a szűkületet okozó gyűrűszalagok bemetszését, valamint az új rehabilitációs kezelési formákat. Végül elemző munkájában megállapítja, hogy a tárgyalt, újabb kezelési módszerek minden bizonnyal javítani fogják a hajlítóín sérülések még ma sem kielégítő funkcionális végeredményeit, azonban változatlanul fontosnak tartja a képzett és gyógyulni akaró beteg együttmúködését.

\section{Kulcsszavak: Hajlítóín; Ínsérülések; Kézsérülések; Kézsebészet; Rehabilitáció; Varrattechnika;}

V. Biró: Recent improvements in the suture techniques and the rehabilitation in the reconstruction of hand flexor tendon injuries. Review of the literature

At the last decade in the reconstruction of flexor tendon injuries could noticed a significant number of revolutionary new leap forward, not only in the surgical techniques, but the postoperative rehabilitation as well. The author in his literary work reviews the new therapeutic methods, first of all the six strand intratendinous sutures. This provides a strong fixation and a compression between the tendon stump and it makes possible an early, active mobilization. Furthermore, he reviews the possibility of the omission in case of epitenon sutures, the incision of the pulleys causing stricture, and the new rehabilitation procedures. Finally he states, that these new therapeutic methods will improve surely the functional end results of the flexor tendon injuries, but he considers important the compliance of the patient.

\section{Keywords: Hand injuries - Surgery/Rehabilitation; Suture techniques; Tendon injuries - Surgery/Rehabilitation;}




\section{BEVEZETÉS}

Az elmúlt évtizedben a kéz 2. zónájában, a hajlítóín sérülések helyreállítása terén számos, forradalmian új előrelépést figyelhettünk meg a sebészi technikában és a műtét utáni rehabilitációban. Mindezekről jelentős számú tudományos közleményben számoltak be; dolgozatunkban idézett publikációjában Tang (29) foglalta össze az ezzel kapcsolatos legújabb ismereteket - több külföldi szerző adatait felhasználva - ezért munkáját vezérfonalnak, alapvető, bázisközleménynek használtuk fel dolgozatunk elkészítéséhez. A hajlítóinak helyreállításának lehetőségeivel (30) számos magyar kutató $(10,17,19,20,21-23)$ mellett e dolgozat szerzője is foglalkozott (1-4).

A több szálból álló intratendinealis varrat alkalmazása (1), a gyűrűszalag(ok) takarékos behasítása és a korai, aktív hajlítási tornagyakorlatok végzése az elmúlt két évtized során, a 2. zónában történt hajlítóín-rekonstrukciók eseteiben az eredmények jelentős javulását eredményezték (29). Ennek oka a sebészi technika és a rehabilitációs kezelések folyamatos fejlődésében keresendő. Dolgozatunkban - a világirodalmi adatok tükrében - összefoglalni kívántunk egyes, szembetűnő fejlődési irányzatot, amelyek átformálhatják a hajlítóín rekonstrukciós eljárásokat.

\section{AZ EPITENON VARRATA}

Korábban (és sok helyütt ma is) az ínvarrat külső vonalában elhelyezett cirkuláris, más elnevezéssel epitenon (az angol nyelvű szakirodalomban perifériásnak nevezett) varrat részét képezte a sérült hajlítóinak mútéti technikájának. E módszert használták egyszerű csomós, tovafutó varrat, keresztezett és még többféle öltés formájában. E perifériás varratok alkalmazását azonban manapság számos kézsebész szakember megfontolandónak, vagy feleslegesnek ítéli meg, amennyiben erős (jól tartó), az ínvégek között kompressziót biztosító intratendinealis ínvarratot sikerül kivitelezni $(5,6,7)$. Ha a szakemberek a fenti elveknek megfelelő varratot végeztek, az eltüntetett minden rést a varratvonalban, és a korai, aktív mozgásterápia során az ínrostokat egyben tartva megelőzte a későbbiekben a rés kialakulását, még annak fejében is, hogy e területen kisebb - az ínvarrat helyén létrejött - csomóképződéssel számolni lehet. Wu és Tang (32) közlése szerint fontos annak megértése, hogy az intratendinealis varratok biztosította kellő feszülés az ínvégek között nagy fontosságú, a közöttük kialakuló résképződés elhárítása céljából. Amennyiben erős, az ínvégek között tartós feszülést biztosító varrat kerül alkalmazásra, az ínvégek közötti kompresszió biztosítottnak látszik (29). Több szerző javaslata szerint $(6,7)$ ilyenkor nincs szükség a perifériás öltés behelyezésére; mindez egyszerübbé teszi a sebészi ellátást és kevesebb - idegen testként szereplő - varróanyag kerül felhasználásra.

\section{A CSOMÓKÉPZŐDÉS}

A szakszerűen felhelyezett és az ínvégek között kompressziót biztosító ínvarrat után létrejött kisfokú csomósodás még tolerálható, és ha a gyűrűszalagok területén kisebb fokú akadály jelentkezne, az a pulley-k takarékos behasításával elhárítható. Tang és munkatársai (28) javasolják, hogy a feszülés mellett helyreállított terület megvastagodása érje el a 120\%-130\% átmérőt a normál ínhoz képest. Giesen és szerzőtársai $(6,7)$ megállapították, hogy ha a varratvonalbeli megvastagodás nem haladja meg az ép ínhoz képest a 150\%-ot, az ín elmozdulása nem károsodott. Mindazonáltal a mútét során a sebésznek meg kell győződnie a megvastagodással együtt járó ínvarratok esetén az akadálytalan extenziós és flexiós mozgásokról; ellenkező esetben a gyűrűszalagok bemetszése nem kerülhető el.

\section{A GYÜRÜSZALAGOK}

Az A2 és az A4 gyűrűszalagok behasítása agresszív eljárásnak tekinthető, mivel a pulley-k épsége eddig szent és sérthetetlen dogmának volt elkönyvelve. Az utóbbi években azonban ez az elgondolás nem állta meg a helyét. Számos kézsebész véleménye szerint az A2 gyűrüszalag egy részének, vagy az A4 teljes egészének a behasítása fontos lépés a jó végeredmények eléréséhez. Az A2 és A4 pulley-ket csak akkor tanácsos behasítani, ha a többi gyűrűszalag ép és az A2-nek egy kis részét sikerül megóvni $(24,25,27,28,33)$. Más szerzők megállapították, hogy betegeiknél, akiknél az A2 pulley-t teljesen eltávolították, nem találtak 
jelentős mozgásproblémát $(6,7,13,14)$. Giesen és munkatársai (7) pedig nem találtak klinikailag diszfunkciót eredményező „bowstringing” hatást (az ujjak hajlító inainak flexiója során a felettük lévő bőr ujjfunkciót gátló előemelkedése), amikor együttesen bemetszették az A3 és az A4 gyűrúszalagokat; egyedül a proximalis interphalangealis ízület felett találtak ilyen, kisfokú, az ujj funkcióját lényegében nem érintő elváltozást. Ennél fogva, hajlítóín varratnál - a jó eredmény érdekében - nem szabad eltekinteni az A4 és az A3 pulley-k, továbbá az ínhüvely behasításától, amelyek az ín zavartalan elcsúszását képesek biztosítani (29).

\section{A REHABILITÁCÓ}

A csukló és az ujjak pozíciójának megítélése az ínhelyreállító mútétek után ma már megváltozott. A korszerű varrattal helyreállított ínnak el kell viselnie a reá háruló feszülést a csukló bármely helyzetében; kivéve az extrém hajlítást, vagy feszítést. Mivel a betegnek igen kellemetlen lehet a csukló nagyobb fokú flexiós, vagy extenziós állásban történt rögzítése, neutrális, vagy enyhén hajlított helyzet javasolt. Az ujjízületeket teljes extenziós állásban tartjuk. Ugyanakkor a metacarpo-phalangealis ízületekben enyhe, vagy mérsékelt hajlítást végezzünk; így csökkenthető a feszülés az ínvarrat területén (29).

A fent leírt rögzítési mód megelőzi a túlzott feszülést az ínvarrat terültén és megtartja a csukló és az ujjak helyzetét a fenti helyzetben. Ezért egy rövid alkari rögzítő sín, a középső, vagy a distalis alkari területig kiterjesztve és a csuklótól az ujjbegyekig érő rögzítés mindenképpen elegendő. Az úgynevezett Manchester rövid sín a csukló területén proximalisan végződik, és lehetővé teszi a csukló szabad mozgását, kivéve a túlzott extenziót $(9,31)$. Több szerző véleménye szerint e rögzítési módszer lehet a legeredményesebb (29).

A szilárd ínvarratot követően a rögzítés eltávolítása az ujjakon végzett passzív és aktív mozgásgyakorlatok csak együttmúködő betegnél megengedettek. E gyakorlatok kivitelezése jobban sikerülhet, ha a csukló funkcionális helyzetben van. Ha a beteg kevésbé együttmúködő, a rehabilitációs kezelésben kevesebb aktív elemet építünk be és a mozgásokat főleg a sín védelmében végeztetjük.

Az ujjak korai, aktív mozgásgyakorlataiban kulcskérdés, hogy az első 2,5-4. héten belül óvjuk a beteget a teljes, aktív ujjflexiótól, azonban mindig végezzünk passzív extenziót és flexiót, mielőtt elkezdjük az óvatos flexiós gyakorlatokat (25-27, 33). Tang és munkatársai (29) ajánlatosnak tartják egyéni, a betegre szabott rehabilitációs terv elkészítését és kivitelezését.

Ami a dolgozatban ismertetett mútéti kezelési és rehabilitációs eljárást illeti, az elmúlt 3 év irodalmi adataink tükrében elmondható, hogy a protokoll szerint végzett mútéteknél (legalább 6 szállal végzett, szilárd rögzítést biztosító ínvarrat, illetve pulley behasítás, az epineuralis varrat elhagyása) csak kevés számú ínruptura fordult elő. Azonban az ínkörüli öszszenövések még mindig problémát jelentettek: a közlések szerint $(7,15,16,28,34)$ 5-10\%-ban igényeltek tendolysis mútétet. Azt azonban hangsúlyozni kell, hogy a kedvezőtlen körülmények között (roncsolt sebzések, nyílt törések, neurovascularis képletek sérüléseivel szövődve, stb.) létrejött hajlítóín sérülések mútéti és rehabilitációs eredményei jóval kedvezőtlenebbek lehetnek, mint az egyszerübb, metszett sérülések eseteiben (29).

\section{A JÖVŐ KIHÍVÁSAI}

Ami a jövő perspektíváit illeti, a 6 szálból álló, szakszerűen elvégzett intratendinalis varrat szilárd rögzítést biztosít, és nagyobb biztonságot nyújt, mint a korábban használt 4 szálból álló ínvarrat $(6,11,12)$. A leírt mútéti technikát alkalmazó szerzők megfigyelték, hogy a 6 szálból álló intratendinealis varrat (és az ín-szegmentumok komprimálása) jobban stabilizálja az ínvégeket és megszünteti a mikromozgásokat közöttük, mint a korábban végzett, 4-szálas tendorrhaphia (28). Az ínvégek közötti stabilitás tovább fokozható, ha a hosszanti varratokat aszimmetrikusan helyezik el (33). A túlzottan nagy szakítószilárdságú varróanyagot a szerzők többsége nem javasolja, a drótvarratot pedig túlzottan merevnek találták $(6,7$, 8, 18), emiatt számos szakember ezeket nem tartja alkalmasnak a 2. zónában a hajlítóinak rekonstrukciójára. 


\section{Összefoglalva:}

Irodalmi áttekintő közleményünkben, a kérdéssel foglalkozó szakemberek véleményét tolmácsolva nem javasoljuk az epitenon körkörös (tovafutó, vagy akár csomós) varratát, amennyiben jól tartó, erős intratendinealis varratot sikerül behelyeznünk, és az ínvégek között kellő kompressziót tudunk a varratok meghúzásával biztosítani. Ilyenkor a varrat területén kisfokú csomósódás lesz megfigyelhető az ínon, azonban ez nem okoz elcsúszási nehezítettséget, amennyiben a teljes A2, vagy az A3 és $A 4$ gyűrűszalagot részlegesen behasítjuk. Javasolt a dolgozatban leírt rövid, csak a csuklót és az ujjakat rögzítő protektív sín viselése és a korai aktív gyógytorna elkezdése. Az ujjak mozgását - úgy tűnik - nem befolyásolja a pulley-k bemetszését követő kisfokú bowstringing jelenség az ujjak hajlító inainál. Végül hozzá kell tennünk, hogy a jó eredmény egyik legfontosabb záloga az együttmúködő és gyógyulni akaró beteg.

\section{IRODALOM}

1. Bíró V.: A varrattechnika fejlödése a kéz hajlitóín-sérüléseiben az elmúlt 15 esztendő során. Orvosi Hetilap, 2016. 157. (6): 212-218. https://doi.org/10.1556/650.2015.30355

2. Bíró V.: Újabb kutatási eredmények a kézhajlitóín sérülések helyreállitásában: A sejtes környezet szerepe. Magyar Traumatológia Ortopédia Kézsebészet Plasztikai Sebészet. 2017. 60. (3-4): 129-135. https://doi.org/10.21755/mto.2017.060.0304.006

3. Bíró V.: Újabb ismeretek a szövetépítés (tissue engineering) lehetöségeiről a kézsebészetben. Irodalmi áttekintés. Orvosi Hetilap. 2018. 159. (34): 1385-1389. https://doi.org/10.1556/650.2018.31150

4. Bíró V.: Újabb lehetőségek a csúszó felszínek helyreállitására a kéz rossz prognózisú hajlítóín sérüléseiben. Doktori Értekezés. Pécs. 1986.

5. Giesen T., Sirotakova M., Copsey A. J., Elliot D.: Flexor pollicis longus primary repair: further experience with the Tang technique and controlled active mobilization. J. Hand Surg. Eur. Vol. 2009. 34. (6): 758-761. https://doi.org/10.1177/1753193408096025

6. Giesen T., Calcagni M., Elliot D.: Primary flexor tendon repair with early active motion: experience in Europe. Hand Clin. 2017. 33. (3): 465-472. https://doi.org/10.1016/i.hcl.2017.03.001

7. Giesen T., Reissner L., Besmens I., Politikou O., Calgagni L.: Flexor tendon repair in the hand with the M-Tang technique (without peripheral sutures), pulley division, and early active motion. J. Hand Surg. Eur. 2018. 43. (5): 474-479. https://doi.org/10.1177/1753193418758269

8. Hay R., A., S., Wong Y., R., Loke A., M., Tay S., C.: Biomechanical investigation of uneven load bearing in six-strand Lim-Tsai flexortendon repairusing Fiber-Loop ${ }^{\circledast}$.J. Hand Surg Eur. 2017. 42. (5):457-461. https://doi.org/10.1177/1753193416681967

9. Howell J. W., Peck F.: Rehabilitation of flexor and extensor tendon injuries in the hand: current updates. Injury. 2013.44. (3): 397-402. https://doi.org/10.1016/j.injury.2013.01.022

10. Kós R.: A kéz sebészete. Budapest. Medicina. 1961.

11. Kozono N., Okada T., Takeuchi N., Shimoto T., Higaki H., Nakashima Y.: A biomechanical comparison between asymmetric Pennington technique and conventional core suture techniques: 6-strand flexor tendon repair. J. Hand Surg. Am. 2018. 43. (1): 79e1-79e8. https://doi.org/10.1016/i.jhsa.2017.06.104

12. Leppänen D. V., Linnanmäki L., Havulinna J., Göransson H.: Suture configurations and biomechanical properties of flexor tendon repairs by 16 hand surgeons in Finland. J Hand Surg Eur. 2016. 41. (8): 831-837. https://doi.org/10.1177/1753193416641624

13. Moriya K., Yoshizu T., Tsubokawa N., Narisawa H., Hara K., Maki Y.: Outcomes of release of the entire A4 pulley after flexor tendon repairs in zone 2A followed by early active mobilization. J. Hand Surg. Eur. 2016. 41. (4): $400-405$. https://doi.org/10.1177/1753193415619082

14. Moriya K., Yoshizu T., Tsubokawa N., Narisawa H., Hara K., Maki Y.: Clinical results of releasing the entire A2 pulley after flexor tendon repair in cone 2C. J. Hand Surg. Eur. 2016. 41. (8): 822-828. https://doi.org/10.1177/1753193416655932

15. Moriya K., Yoshizu T., Tsubokawa N., Narisawa H., MatsuzawaS., Maki Y.: Outcomes offlexortendon repairs in zone 2 subzones with early active mobilization. J Hand Surg Eur. 2017. 42. (9): 896-902. https://doi.org/10.1177/1753193417715213

16. Pan Z. J., Qin J., Zhou X., Chen J.: Robust thumb flexor tendon repairs with a six-strand M-Tang method, pulley venting, and early active motion. J. Hand Surg Eur. 2017. 42. (9): 909-914. https://doi.org/10.1177/1753193417723238

17. Renner A., Sántha E.: A kéz sebészete. Budapest. Kadix Press Kiadó. 2014.

18. Rigó I., Z., Haugstvedt J., R., Røkkum M.: The effect of adding active flexion to modified Kleinert regime on outcomes for zone 1 to 3 flexor tendon repairs. A prospective randomized trial. J Hand Surg Eur. Vol. 2017.42. (9): 920-929. https://doi.org/10.1177/1753193417728406

19. Salamon A.: A sérült ujjhajlitó ín gyógyulásának molekuláris és sejtes szabályozása a II. zónában. Magyar Traumatológia Ortopédia Kézsebészet Plasztikai Sebészet, 2006. 49. (2): 121-129. 
20. Salamon A.: Az intranszplantátumok funkcionális alkalmazkodása a kollagén újdon-képződés strukturális változásának függvényében. Doktori Értekezés. Szombathely. 1979.

21. Sántha E.: A hajlítóinak sérülései és betegségei. In: Renner A., Sántha E.: A kéz sebészete. Budapest. Kadix Press. 2014. 233-242. $p$.

22. Sántha E.: Szemléleti változások a kéz hajlitóín sérüléseinek helyreállitásában. Orv. Hetil. 1979. 120: 2659.

23. Sántha E.: Újabb lehetöségek a kéz hajlitóín sérüléseinek ellátásában. Kandidátusi Értekezés. Székesfehérvár, 1981.

24. Tang J., B.: Clinical outcomes associated with flexor tendon repair. Hand Clin. 2005. 21. (2): $199-210$. https://doi.org/10.1016/i.hcl.2004.11.005

25. Tang J., B.: Indications, methods, postoperative motion and outcome evaluation of primary flexor tendon repairs in zone 2. J. Hand Surg. Eur. 2007. 32. (2): 118-129. https://doi.org/10.1016/i.ihsb.2006.12.009

26. Tang J., B.: Outcomes and evaluation of flexor tendon repair. Hand Clin. 2013. 29. (2): 251-259.

27. Tang J. B.: Release of the A4 pulley to facilitate zone II flexor tendon repair. . J. Hand Surg. Am. 2014. 39. (11): $2300-2007$. https://doi.org/10.1016/j.jhsa.2014.08.025

28. Tang J., B., Xhou, X., Pan Z., J., Qing J., Gong K., T., Chen J.: Strong digital flexor tendon repair, extension-flexion test, and early active flexion: experience in 300 tendons. Hand Clin. 2017. 33. (3): 455-463. https://doi.org/10.1016/j.hcl.2017.04.012

29. Tang J., B.: Recent evolutions in flexor tendon repairs and rehabilitation. J. Hand Surg. Eur. Vol. 2018. 43. (5): $469-473$. https://doi.org/10.1177/1753193418773008

30. Vízkelety T. (Föszerk.): A Magyar Ortopédia, Traumatológia és határterületei bibliográfiája, a kezdetektöl napjainkig. Budapest. A Magyar Traumatológus Társaság, a Magyar Ortopéd Társaság, a Magyar Kézsebész Társaság s a Magyar Plasztikai Sebész Társaság kiadása. 2007.

31. Wong J. K., Peck F.: Improving results of flexor tendon repair and rehabilitation. Plast. Reconstr. Surg. 2014. 134. (6): 913e-925e. https://doi.org/10.1097/prs.0000000000000749

32. Wu Y. F., Tang, J. B.: Effects of tension across the tendon repair site on tendon gap and ultimate strength. J. Hand Surg. Am. 2012. 37. (5): 906-912. https://doi.org/10.1016/i.jhsa.2012.01.004

33. Wu Y., Tang J., B.: Recent developments in flexor tendon repair techniques and factors influencing strength of the tendon repair. J. Hand Surg. Eur. 2014. 39. (1): 6-19. https://doi.org/10.1177/1753193413492914

34. Zhou X., Li X., R., Qing J., Jia X., F., Chen J.: Outcomes of the six-strand M-Tang repair for zone 2 primary flexor tendon repair in 54 fingers. J Hand Surg Eur. 2017. 42. (5): 462-468. https://doi.org/10.1177/1753193417691390

\section{Prof. Bíró Vilmos, M.D., Ph.D., D.Sc.}

7633 Pécs, Hajnóczy u. 25/a., II. em. 2.

E-mail: biro.vilmos2@chello.hu 